\title{
Atmospheric amines and ammonia measured with a chemical ionization mass spectrometer (CIMS)
}

\author{
Y. You ${ }^{1}$, V. P. Kanawade ${ }^{2}$, J. A. de Gouw ${ }^{3}$, A. B. Guenther ${ }^{4,5}$, S. Madronich ${ }^{6}$, M. R. Sierra-Hernández ${ }^{7}$, M. Lawler ${ }^{6,8}$, \\ J. N. Smith ${ }^{6,8}$, S. Takahama ${ }^{9}$, G. Ruggeri ${ }^{9}$, A. Koss ${ }^{3}$, K. Olson ${ }^{10}$, K. Baumann ${ }^{11}$, R. J. Weber ${ }^{12}$, A. Nenes ${ }^{12,13}$, \\ H. Guo ${ }^{12}$, E. S. Edgerton ${ }^{11}$, L. Porcelli ${ }^{1}$, W. H. Brune ${ }^{14}$, A. H. Goldstein ${ }^{10}$, and S.-H. Lee \\ ${ }^{1}$ Kent State University, College of Public Health, Kent, Ohio, USA \\ ${ }^{2}$ Indian Institute of Technology - Kanpur, Department of Civil Engineering and Center for Environmental Science \& \\ Engineering, Kanpur, India \\ ${ }^{3}$ National Oceanic and Atmospheric Administration, Chemical Science Division, Boulder, Colorado, USA \\ ${ }^{4}$ Pacific Northwest National Laboratory, Richland, Washington, USA \\ ${ }^{5}$ Washington State University, Department of Civil and Environmental Engineering, Pullman, Washington, USA \\ ${ }^{6}$ National Center for Atmospheric Research, Atmospheric Chemistry Division, Boulder, Colorado, USA \\ ${ }^{7}$ Ohio State University, Byrd Polar Research Center, Columbus, Ohio, USA \\ ${ }^{8}$ University of Eastern Finland, Applied Physics Department, Kuopio, Finland \\ ${ }^{9}$ Ecole Polytechnique Federale de Lausanne, Institute d'Ingenierie de l'Environment, Lausanne, Suisse, Switzerland \\ ${ }^{10}$ University of California - Berkeley, Department of Environmental Science, Policy and Management, Berkeley, \\ California, USA \\ ${ }^{11}$ Atmospheric Research and Analysis, Inc., Morrisville-Cary, North Carolina, USA \\ ${ }^{12}$ Georgia Institute of Technology, School of Earth and Atmospheric Sciences, Atlanta, Georgia, USA \\ ${ }^{13}$ Georgia Institute of Technology, School of Chemical and Biomolecular Engineering, Atlanta, Georgia, USA \\ ${ }^{14}$ Penn State University, Department of Meteorology, University Park, Pennsylvania, USA
}

Correspondence to: S.-H. Lee (slee19@kent.edu)

Received: 27 May 2014 - Published in Atmos. Chem. Phys. Discuss.: 20 June 2014

Revised: 5 October 2014 - Accepted: 14 October 2014 - Published: 19 November 2014

\begin{abstract}
We report measurements of ambient amines and ammonia with a fast response chemical ionization mass spectrometer (CIMS) in a southeastern US forest and a moderately polluted midwestern site during the summer. At the forest site, mostly $\mathrm{C} 3$-amines (fromptv to tens of pptv) and ammonia (up to 2 ppbv) were detected, and they both showed temperature dependencies. Aerosol-phase amines measured thermal-desorption chemical ionization mass spectrometer (TDCIMS) showed a higher mass fraction in the evening with cooler temperatures and lower in the afternoon with warmer temperatures, a trend opposite to the gas-phase amines. Concentrations of aerosol-phase primary amines measured with Fourier transform infrared spectroscopy (FTIR) from micron and submicron particles were 2 orders of magnitude higher than the gas-phase amines. These results indicate that gas to particle conversion is one
\end{abstract}

of the major processes that control the ambient amine concentrations at this forest site. Temperature dependencies of C3-amines and ammonia also imply reversible processes of evaporation of these nitrogen-containing compounds from soil surfaces in daytime and deposition to soil surfaces at nighttime. During the transported biomass burning plume events, various amines (C1-C6) appeared at the pptv level, indicating that biomass burning is a substantial source of amines in the southeastern US. At the moderately polluted Kent site, there were higher concentrations of C1- to C6amines (pptv to tens of pptv) and ammonia (up to $6 \mathrm{ppbv}$ ). C1- to C3-amines and ammonia were well correlated with the ambient temperature. C4- to C6-amines showed frequent spikes during the nighttime, suggesting that they were emitted from local sources. These abundant amines and ammonia may in part explain the frequent new particle forma- 
tion events reported from Kent. Higher amine concentrations measured at the polluted site than at the rural forested site highlight the importance of constraining anthropogenic emission sources of amines.

\section{Introduction}

Amines and ammonia $\left(\mathrm{NH}_{3}\right)$ are ubiquitous in the atmosphere and they are present in the gas phase, aerosol particles, and rain and fog droplets (Ge et al., 2010b). Atmospheric sources of amines and $\mathrm{NH}_{3}$ include animal husbandry, vegetation, biomass burning, oceans, waste incinerators, cooking, tobacco smoking, car exhausts, and various industrial processes (Ge et al., 2010a, b; Hertel et al., 2013). Some of the current $\mathrm{CO}_{2}$ sequestration technologies also utilize amine solutions and this has become an important source of anthropogenic amines in the atmosphere (Shao and Stangeland, 2009). Amines can cause serious health effects (Ge et al., 2010b; Lee and Wexler, 2013), as they can be rapidly oxidized to form carcinogens, such as nitrosamines and isocyanic acid in the atmosphere (Finlayson-Pitts and Pitts, 2000; Nielsen et al., 2011, 2012). The background concentrations of amines are typically at the pptv (parts per trillion in volume mixing ratio) to tens of pptv level in the gas phase (Akyüz, 2007; Chang et al., 2003; Dawson et al., 2014; Grönberg et al., 1992; Hanson et al., 2011; Kieloaho et al., 2013; Schade, 1995; Sellegri et al., 2005b; VandenBoer et al., 2011; Yu and Lee, 2012), whereas $\mathrm{NH}_{3}$ is typically at the sub-ppbv (parts per billion in volume mixing ratio) to tens of ppbv level (Benson et al., 2010; Erupe et al., 2010; Fountoukis et al., 2009; Nowak et al., 2006, 2007, 2010).

Amines and $\mathrm{NH}_{3}$, together with sulfuric acid, play critical roles in atmospheric new particle formation processes (Zhang et al., 2012). Quantum chemical calculations suggested that amines can reduce the energy barrier of sulfuric acid nucleation, even more effectively than $\mathrm{NH}_{3}$ (Kurtén et al., 2008). Laboratory studies showed that amines can substitute ammonium to aminium in charged clusters (Lloyd et al., 2009). Studies of nucleation kinetics showed that amines indeed participate in the sulfuric acid aerosol nucleation at the molecular cluster level (Almeida et al., 2013; Berndt et al., 2010; Karl, 2010; Wang et al., 2010a, 2010b; Yu et al., 2012; Zollner et al., 2012). The enhancement effects of amines on nucleation are dependent on the basicity of amines; there are also synergetic effects of amines and $\mathrm{NH}_{3}$ on aerosol nucleation (Yu et al., 2012).

Amines and $\mathrm{NH}_{3}$ participate in secondary organic aerosol (SOA) formation via various pathways including formation of salts (Angelino et al., 2001; Murphy et al., 2007), oxidation reactions (Angelino et al., 2001; Gai et al., 2010; Karl, 2010; Malloy et al., 2009; Murphy et al., 2007; Nielsen et al., 2011; Silva et al., 2008; Updyke et al., 2012; Zahardis et al., 2008) and aqueous phase reactions (De Haan et al.,
2009). These nitrogen containing compounds also contribute to the formation of light absorbing organic compounds in atmospheric "brown carbon" aerosols (Laskin et al., 2010). Amines and $\mathrm{NH}_{3}$ affect the aerosol acidity (Pankow, 2003; Pratt et al., 2009), a key aerosol property that may control the formation yields of biogenic SOA (Jang et al., 2002; Surratt et al., 2007). Ammonium sulfate and aminium sulfate salts have distinctively different deliquescent relative humidity (RH) points (Qiu and Zhang, 2013) and in turn affect the aerosol phase state (solid vs. liquid); this may have important implications for aerosol processes, such as SOA formation yields (Vaden et al., 2011).

Amines have been measured typically with low time resolution (hours, days or even weeks) online and often with offline analytical methods based on chromatography, mass spectrometry, UV, fluorescence or electrochemical detectors (Ge et al., 2010b; Yu and Lee, 2012). These methods are not suitable for capturing temporal variations of atmospheric amines that can rapidly change due to emissions and deposition processes, as well as reactions with oxidants and aerosols. Chemical ionization mass spectrometry (CIMS) has been used for the fast-response online detection of atmospheric amines (Eisele, 1988; Hanson et al., 2011; Sellegri et al., 2005b; Yu and Lee, 2012). Sellegri et al. (2005b) used a proton transfer reaction mass spectrometer (PTRMS) to measure trimethylamine and other volatile organic compounds (VOCs) in the Finnish boreal forest. Hanson et al. (2011) developed an ambient pressure proton transfer mass spectrometer (AmPMS) technique to measure gasphase C1- to C6-amines in downtown Atlanta, Georgia. Yu and Lee (2012) developed a CIMS detection method that utilizes ethanol ions as chemical reagent to simultaneously detect amines and $\mathrm{NH}_{3}$, and conducted ambient measurements in Kent, Ohio.

Measurements of amines in the forested environments are very scarce at present. Schade (1995) suggested that trimethylamine could be the main aliphatic amine compound emitted from vegetation sources. Forest soils also contain dissolved organic nitrogen compounds such as free amino acids and alkylamines, due to biodegradation of proteins and peptides in the forest ecosystem (Bigg, 2004; Yu et al., 2002). An early PTR-MS measurement in the boreal forest by (Sellegri et al., 2005a) reported C3-amines between 30-80 pptv in the spring. Another measurement at the same site with a liquid chromatography technique showed even higher concentrations of reduced nitrogen compounds between May and October, $\mathrm{C} 2$ - and $\mathrm{C} 3$-amines at levels of up to hundreds of pptv, and C4-amines up to tens of pptv, and suggested that amines may be emitted from leaf litters (Kieloaho et al., 2013).

In the present study, we report the ambient concentrations of amines and $\mathrm{NH}_{3}$ measured in an Alabama forest and in Kent, Ohio during the summer of 2013. The Alabama site represents a relatively rural forest environment typical for the southeastern US environments with high biogenic VOCs 
emissions, while Kent is located in the Midwest surrounded by large power plants and agricultural activities at the regional scale. Observations at these two relatively contrasting environments can provide information that is helpful to identify emission sources, sinks and the chemistry of atmospheric amines and $\mathrm{NH}_{3}$. This study presents one of the very few simultaneous measurements of ambient amines and $\mathrm{NH}_{3}$ with a fast response CIMS. To our best knowledge, this is the first time that measurements of amines were made in a rural biogenic VOC-dominated environment in the southeastern US.

\subsection{Measurement sites}

Measurements were made at the Southeastern Aerosol Research and Characterization (SEARCH) Centreville, AL site (near Brent, AL) during the Southern Oxidant and Aerosol Study (SOAS, http://soas2013.rutgers.edu/) from June 1 to 15 July 2013. The main objective of SOAS is to study the atmospheric chemistry and climate-relevant properties of aerosols generated from interactions of biogenic and anthropogenic emissions. Brent $\left(32.94^{\circ} \mathrm{N}, 87.18^{\circ} \mathrm{W}\right)$ has a population of less than 5000 inhabitants and is surrounded by mixed deciduous (oak, hickory, and sweetgum) and coniferous (loblolly and shortleaf pine) trees, resulting in high ambient ratios of isoprene to monoterpenes. It is located about $85 \mathrm{~km}$ south of Birmingham and $40 \mathrm{~km}$ southeast of Tuscaloosa. The measurement site is approximately 30 and $40 \mathrm{~km}$ away from the US Interstate Highways 20 and 65, respectively, and is within $5 \mathrm{~km}$ of the State Highway 82 . Several large emission sources of $\mathrm{NO}_{\mathrm{x}}\left(\mathrm{NO}+\mathrm{NO}_{2} ; 17000\right.$ ton year $\left.{ }^{-1}\right)$ and $\mathrm{SO}_{2}$ (92000 ton year ${ }^{-1}$ ) are located within $100 \mathrm{~km}$ of the measurement site. This forest site thus can represent contrasting air masses, where at times atmospheric constituents are mostly of biogenic origin and at other times biogenic air masses are mixed with pollutant $\mathrm{NO}_{\mathrm{x}}$ and $\mathrm{SO}_{2}$ emissions.

Following the SOAS campaign, subsequent measurements were made in Kent $\left(41.15^{\circ} \mathrm{N}, 81.36^{\circ} \mathrm{W}\right)$ over 20 days during August and September 2013. The Kent site was previously described elsewhere (Benson et al., 2010; Erupe et al., 2010; Kanawade et al., 2012; Yu et al., 2013). Kent has a high tree cover fraction, and has a population of about 30000 . It is surrounded by several larger cities: Akron/Canton about $30 \mathrm{~km}$ to the southwest, Cleveland about $65 \mathrm{~km}$ to the northwest, and Pittsburgh about $160 \mathrm{~km}$ to the east. There are two interstate highways near the measurement site, US Interstate 76 about $5 \mathrm{~km}$ south of the sampling site and Interstate 80 about $10 \mathrm{~km}$ north of the site. There are high emissions of $\mathrm{SO}_{2}$ (http://www.epa.gov/air/sulfurdioxide/) from the large size coal-burning power plants located in the Ohio River valley region. There are also widespread agricultural activities in Northeast Ohio. Kent also represents one of the very few observation sites in the US where long-term measurements of new particle formation were conducted, including aerosol size distributions and key nucleation precursors (sulfuric acid, $\mathrm{NH}_{3}$ and amines) (Benson et al., 2010; Erupe et al., 2010; Kanawade et al., 2012; Yu et al., 2013). Observations conducted over the past 8 years consistently showed frequent new particle formation events, with the frequency between $\sim 17 \%$ and $\sim 40 \%$, over different seasons at this site.

\section{Amine-CIMS characterization and calibration}

The amines/ $\mathrm{NH}_{3}$ CIMS was described elsewhere (Yu and Lee, 2012). As discussed in detail below, this CIMS detects ambient amines and $\mathrm{NH}_{3}$ at the pptv and sub-pptv level, with a 1 min integration time. The sensitivity ranged between 2$12 \mathrm{~Hz} \mathrm{pptv}^{-1}$ for different amine and $\mathrm{NH}_{3}$ for $1 \mathrm{MHz}$ of protonated ethanol reagent ion signals, as determined from in situ calibrations (Table 1).

$\mathrm{NH}_{3}$ and amines (such as methylamine, dimethylamine, ethylamine, trimethylamine, diethylamine, and triethylamine etc. and their isomers, denoted as B below) are ionized using ethanol ions as reagent, via the following ion-molecule reactions (Erupe et al., 2011; Yu and Lee, 2012):

$$
\begin{aligned}
& \left(\mathrm{C}_{2} \mathrm{H}_{5} \mathrm{OH}\right)_{n} \mathrm{H}^{+}+\mathrm{NH}_{3} \rightarrow\left(\mathrm{C}_{2} \mathrm{H}_{5} \mathrm{OH}\right)_{n-1} \mathrm{NH}_{4}^{+} \\
& +\mathrm{C}_{2} \mathrm{H}_{5} \mathrm{OH}, \\
& \left(\mathrm{C}_{2} \mathrm{H}_{5} \mathrm{OH}\right)_{n} \mathrm{H}^{+}+\mathrm{B} \rightarrow \mathrm{BH}^{+}+n \mathrm{C}_{2} \mathrm{H}_{5} \mathrm{OH},
\end{aligned}
$$

where $n=1,2$, and 3. A collision dissociation cell (CDC) is used in the CIMS to destroy the weakly bounded clusters, and thus primary ethanol ions typically contain $\mathrm{n}$ only up to 3. As shown in the CIMS spectra (Fig. 1), there were ethanol monomer, dimer, and trimmer reagent ions; whereas for product ions there were only $\mathrm{BH}^{+}$ions. The ethanol ion chemistry for the detection of $\mathrm{NH}_{3}$ was worked out previously by Nowak and colleagues (Nowak et al., 2002), and we have linearly applied the same technique to the detection of amines (Erupe et al., 2011; Yu and Lee, 2012).

The CIMS was located in a trailer at the SOAS ground site. Ambient air was sampled through a $13 \mathrm{~cm}$ long perfluoroalkoxy (PFA) Teflon tube (diameter, $1.27 \mathrm{~cm}$ ) and a subsequent $17 \mathrm{~cm}$ long PFA tube (diameter, $0.635 \mathrm{~cm}$ ) with a flow rate of $10 \mathrm{~L} \mathrm{~min}^{-1}$ (liter per minute) (Fig. S1). The residence time within the sampling inlet prior to the CIMS ionization region was $0.17 \mathrm{~s}$. The sampling inlet was drilled through the wall of the trailer, horizontally, in the direction precisely aligned with the CIMS inlet. Only PFA and polytetrafluoroethylene (PTFE) Teflon material (as opposed to stainless or aluminum) were used to reduce the deposition of ammonium nitrate and $\mathrm{NH}_{3}$ on the inner surfaces of the sampling inlet (Nowak et al., 2007). CIMS background signals were obtained by introducing ambient air through another PFA Teflon tube (inner diameter, $0.635 \mathrm{~cm}$ ) (Fig. S1). A threeway valve, which was also made of PFA, was used to switch the sampling between the ambient and background measurement modes. Ambient and background measurements were conducted over 15 and $5 \mathrm{~min}$, respectively, within every 20 min period. During the background mode, ambient air 


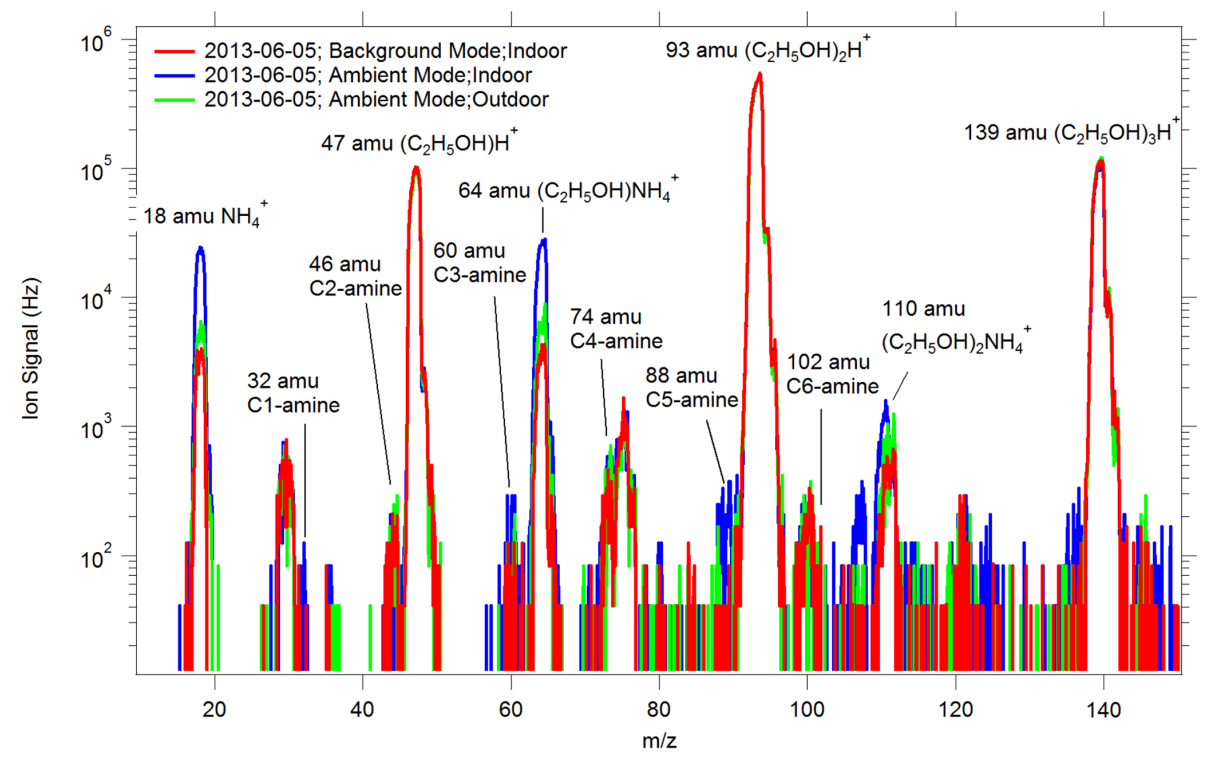

Figure 1. Typical CIMS mass spectra taken under the background (red) and measurement modes, including measurements from the ambient air (green) and indoor air (blue), in the Alabama forest. $Y$ axis is shown in log scale.

Table 1. The CIMS sensitivities (normalized to $1 \mathrm{MHz}$ ethanol reagent ions) determined by in situ calibrations (Fig. S1), background signals, and detection limits ( 3 times the standard deviation of background signals, within a 1 min integration time) of amines and $\mathrm{NH}_{3}$. Typical ambient concentrations measured in the Alabama forest and in Kent are also included (20 min average data).

\begin{tabular}{lcccc}
\hline Basic Compound $^{\text {a }}$ & $\begin{array}{c}\text { Sensitivity } \\
{\left[\mathrm{Hz}\left(\mathrm{pptv} \mathrm{MHz}^{-1}\right]^{\mathrm{b}}\right.}\end{array}$ & $\begin{array}{c}\text { Detection Limit, } \\
\text { DL }\end{array}$ & $\begin{array}{c}\text { Alabama Forest: } \\
\text { Jun-Jul }\end{array}$ & $\begin{array}{c}\text { Kent: } \\
\text { Aug-Sep }\end{array}$ \\
\hline $\mathrm{NH}_{3}$ (ppbv) & 13 & 0.035 & Up to 1-2 & Up to 6 \\
C1-Amine (pptv) (methylamine) & 12 & 0.1 & $<\mathrm{DL}$ & $1-4$ \\
C2-Amines (pptv) (dimethylamine) & 12 & 0.5 & $<\mathrm{DL}$ & $<\mathrm{DL}$ \\
C3-Amines (pptv) (trimethylamine) & 8 & 0.8 & $1-10$ & $5-10$ \\
C4-Amines (pptv) (diethylamine) & 4 & 3.3 & $<\mathrm{DL}$ & $10-50$ \\
C5-Amines (pptv) & 2 & 1.9 & $<\mathrm{DL}$ & $10-100$ \\
C6-Amines (pptv) (triethylamine) & 2 & 1.4 & $<\mathrm{DL}$ & $<$ DL \\
\hline
\end{tabular}

${ }^{a}$ CIMS shows the sum of isomer concentrations. Here, we indicate specific amine compounds used in calibration. For example, for $\mathrm{C} 3$-amines, trimethylamine was used for calibration. But for $\mathrm{C} 5$-amines, no calibrations were made because permeation tubes are not available and its sensitivity was interpolated between those for C4- and C6-amines.

${ }^{\mathrm{b}}$ With regard to the unit of sensitivity $\left(\mathrm{Hz}(\mathrm{pptv} \mathrm{MHz})^{-1}\right)$ : sensitivity was defined as the change in ion signals $(\mathrm{Hz})$ of a basic compound corresponding to $1 \mathrm{pptv}$ of the calibration gas concentration, then normalized to $1000000 \mathrm{~Hz}$ of the ethanol reagent ion signal.

passed first through a diffusion drier (DDU 570/H, Particle Instruments) containing silica-gel to remove water vapor, and then through the silicon phosphate scrubbers (AS-200-8-EB, Perma Pure) to remove amines and $\mathrm{NH}_{3}$ (Yu and Lee, 2012). The drier was used to prolong the lifetime of the scrubber; the scrubber does not efficiently remove basic compounds when it is wet. The drier was needed, especially under high $\mathrm{RH}$ conditions in summer in Alabama. Our experiments using ambient air, without applying the drier, have shown that ambient RH did not affect the CIMS background ion signals. We also experimentally confirmed that the application of the drier did not change the background signals. Linear interpolation of background signals was made between two consecutive background measurements. Normalization of background and ambient signals was made against the total ethanol ion signals including monomer, dimer and trimer cluster ions by assuming the same transmission efficiency for different clusters, to take into account the variation of ethanol ion signals between the background and sampling modes due to fluctuations of the flow and pressure in the ionization cell. The reagent ion signals were typically around $300 \mathrm{kHz}$, with differences less than $10 \%$ between the two modes (higher during the background than the sampling mode).

In situ calibrations were made for various amines and $\mathrm{NH}_{3}$. Two separate and independent gas handling systems were built for the calibration and background/ambient mode measurements; this is a different approach than was used for our previous studies (Benson et al., 2010; Yu and Lee, 2012). 


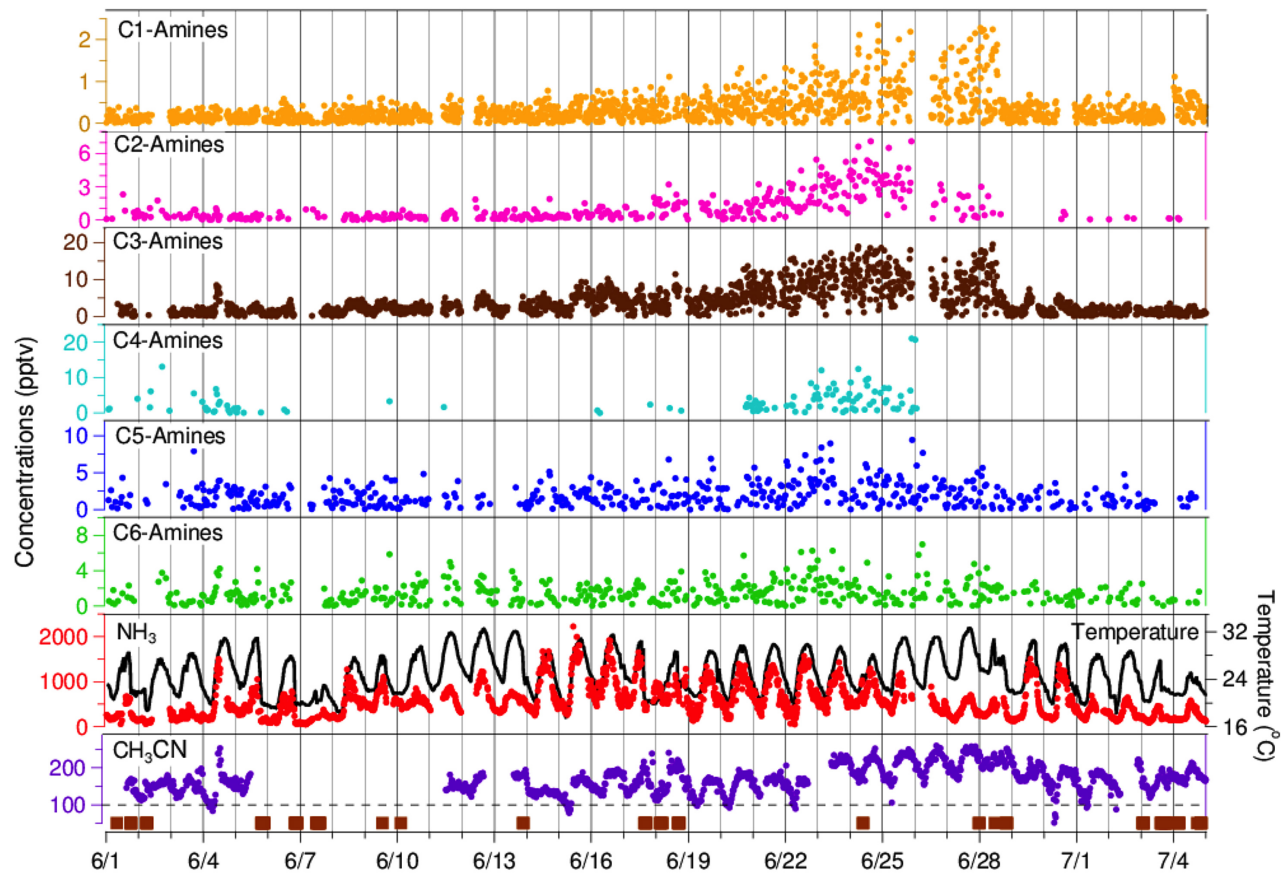

Figure 2. Temporal variations of amines, $\mathrm{NH}_{3}$, and $\mathrm{CH}_{3} \mathrm{CN}$ along with the ambient temperature measured in the Alabama forest during the entire SOAS field campaign. Vertical grids correspond to times at midnight. The brown colored bars in the bottom panel indicate the period of rainfalls. Concentrations of amines and $\mathrm{NH}_{3}$ data shown here were averaged over 20 min; the same for Figs. 3, 8 and 10 .

This modification was made to reduce possible contamination of standard calibration gases on the inlet inner surfaces. Amines and $\mathrm{NH}_{3}$ calibration gases were generated from precalibrated National Institute of Standards and Technology (NIST) traceable permeation tubes in a temperature- and flow rate-controlled standard gas generator (491 MB, Kin-Tek). Each standard gas was run continuously for $20 \mathrm{~h}$ prior to the calibration to ensure that the vapor was fully stabilized in the oven.

Figure 1 shows the typical CIMS mass spectra taken under the background and measurement modes (for the indoor and ambient air) during the SOAS campaign. Reagent ethanol ion peaks appeared at $m / z \quad 47\left(\mathrm{C}_{2} \mathrm{H}_{5} \mathrm{OH}\right) \mathrm{H}^{+}$, $m / z 93\left(\mathrm{C}_{2} \mathrm{H}_{5} \mathrm{OH}\right)_{2} \mathrm{H}^{+}$(the highest peak) and $\mathrm{m} / z 139$ $\left(\mathrm{C}_{2} \mathrm{H}_{5} \mathrm{OH}\right)_{3} \mathrm{H}^{+} . \mathrm{NH}_{3}$ product ions appeared at $m / z 18 \mathrm{NH}_{4}^{+}$, $m / z 64\left(\mathrm{C}_{2} \mathrm{H}_{5} \mathrm{OH}\right) \mathrm{NH}_{4}^{+}$, and $m / z \quad 110\left(\mathrm{C}_{2} \mathrm{H}_{5} \mathrm{OH}\right)_{2} \mathrm{NH}_{4}^{+}$. $\mathrm{C} 1$-amine (methylamine) ions were at $m / z 32\left(\mathrm{CH}_{3}\right) \mathrm{NH}_{3}^{+}$; $\mathrm{C} 2$-amines at $m / z \quad 46$ (e.g., $\left(\mathrm{CH}_{3}\right)_{2} \mathrm{NH}_{2}^{+}$, dimethylamine; $\mathrm{CH}_{3} \mathrm{CH}_{2} \mathrm{NH}_{2}^{+}$, ethylamine); $\mathrm{C} 3$-amines at $\mathrm{m} / \mathrm{z} 60$ (e.g., $\left(\mathrm{CH}_{3}\right)_{3} \mathrm{NH}^{+}$, trimethylamine]; C4-amines at $m / z 74$ (e.g., $\left(\mathrm{C}_{2} \mathrm{H}_{5}\right)_{2} \mathrm{NH}_{2}^{+}$, diethylamine]; $\mathrm{C} 5$-amines at $\mathrm{m} / z$ 88; and C6-amines at $m / z, 102$ (e.g., $\left(\mathrm{C}_{2} \mathrm{H}_{5}\right)_{3} \mathrm{NH}^{+}$, triethylamine). We generally found significantly higher concentrations of amines and $\mathrm{NH}_{3}$ in the indoor than in the ambient air, indicating direct emissions of nitrogen containing basic compounds from human bodies (e.g., sweat and breath) (Sutton et al., 2000). For example, on the specific day shown in Fig. 1, we estimated that there were $\mathrm{NH}_{3} 4.9 \mathrm{ppbv}, \mathrm{C} 1$-amine $14 \mathrm{pptv}$,
C2-amines 20 pptv, C3-amines 30 pptv, C5-amines 183 pptv, and C6-amines $181 \mathrm{pptv}$ in the indoor air; and there were $\mathrm{NH}_{3} 0.62 \mathrm{ppbv}, \mathrm{C} 3$-amines $16 \mathrm{pptv}$ and C6-amines $73 \mathrm{pptv}$ in the ambient air. The indoor air concentrations were extremely sensitive to the presence of people inside the room.

Table 1 summarizes the CIMS sensitivities of amines and $\mathrm{NH}_{3}$ obtained from in situ calibrations, background signals, and detection limits (DL, defined as 3 times the standard deviation of the background ion signals, with 1 min integration time). Tables $\mathrm{S} 1$ and $\mathrm{S} 2$ show detection limits of each amine compound and $\mathrm{NH}_{3}$ derived for different integration times ( 1 , 5,10 , and $60 \mathrm{~s}$ ) from measurements made during the SOAS campaign and in Kent, Ohio. In general, detection limits leveled off after 5-10 s. Table S3 shows mean values of background signals measured at the two sites. The background signals were fairly stable over the entire measurement periods. Figure $\mathrm{S} 2$ shows the calibration curves of amines and $\mathrm{NH}_{3}$ obtained in situ in the Alabama forest. The sensitivity of $\mathrm{NH}_{3}$ was highly reproducible (Fig. S2), $\sim 13 \mathrm{~Hz} \mathrm{pptv}^{-1}$ for $1 \mathrm{MHz}$ of ethanol reagent ions, for the entire SOAS campaign as well as the pre- and post-campaign calibrations. This is an important improvement made over the previous studies (Benson et al., 2010; Yu and Lee, 2012), where $\mathrm{NH}_{3}$ sensitivities varied on a day-to-day basis. Although the sensitivities of amines were also improved, amine sensitivities were still lower than the $\mathrm{NH}_{3}$ sensitivity and measurements of amines were also less reproducible (Figs. S2 and Table 1). Lower amine sensitivities were due to loss of amines in the gas-line. 

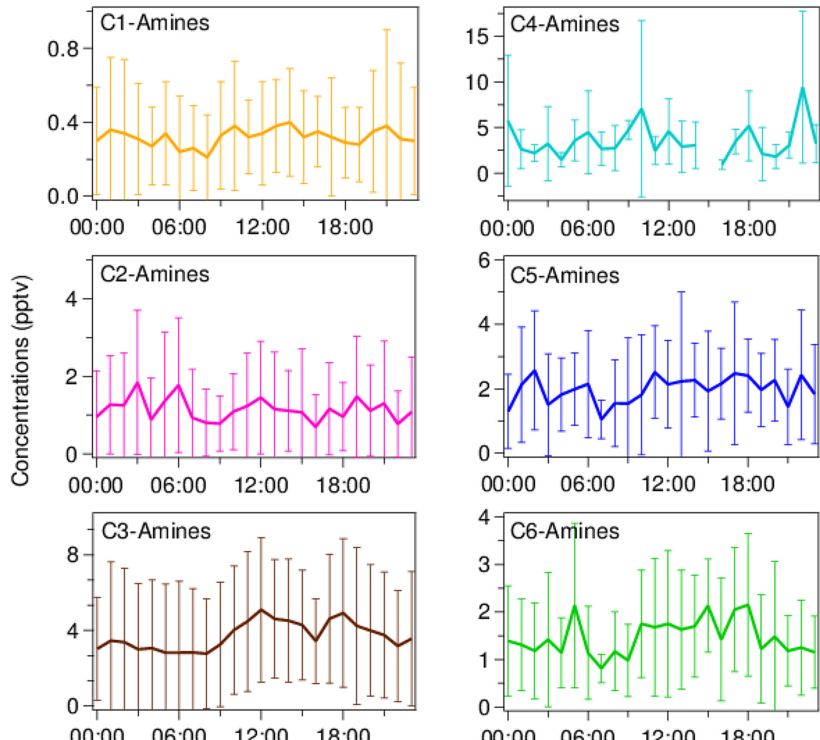

00:00 06:00 12:00 18:00
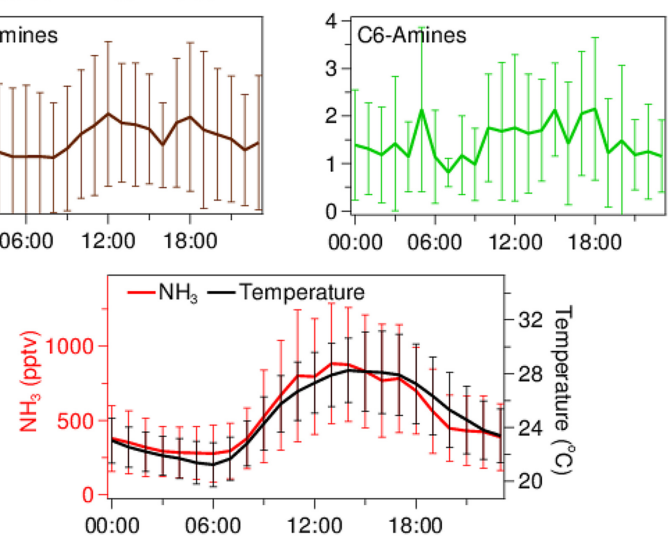

Figure 3. The averaged diurnal variation throughout the entire SOAS campaign for the measured $\mathrm{C} 1$ - to $\mathrm{C} 6$-amines and $\mathrm{NH}_{3}$ concentrations measured in the Alabama forest during the summer for 6 weeks. C4-amines were below the detection limit for most of the time during the campaign, except the burning events (Fig. 2), so are not shown here. The vertical bars indicate one standard deviation of the measurement values, representative of day-to-day fluctuations in ambient concentrations (Fig. 2). The average ambient temperature is also shown, along with $\mathrm{NH}_{3}$.

Consistent with this observation, the measured sensitivities also showed a decreasing trend with the increasing molecular weight of the amine molecule (Table 1). Detection limits were also substantially improved, compared to the previous work (Yu and Lee, 2012). These improvements in the detection limits and sensitivities were achieved because background signals (Table S3) were lower, less variable and independent of ambient RH conditions.

Amines have been measured with CIMS techniques in other studies, using protonated water ions as reagent (Hanson et al., 2011; Sellegri et al., 2005a). Because ethanol has a higher proton affinity $\left(788 \mathrm{~kJ} \mathrm{~mol}^{-1}\right)$ than water $\left(697 \mathrm{~kJ} \mathrm{~mol}^{-1}\right)$ (Jolly, 1991), our CIMS only responds to basic compounds that have higher proton affinities (e.g., trimethylamine $945 \mathrm{~kJ} \mathrm{~mol}^{-1} ; \mathrm{NH}_{3} 854 \mathrm{~kJ} \mathrm{~mol}^{-1}$ ) and hence are selectively detected (via R1 and R2) with little interferences from other VOCs present in the atmosphere. Since most VOCs are detected at odd masses, in general, even masses are good indicators for nitrogen-containing com-
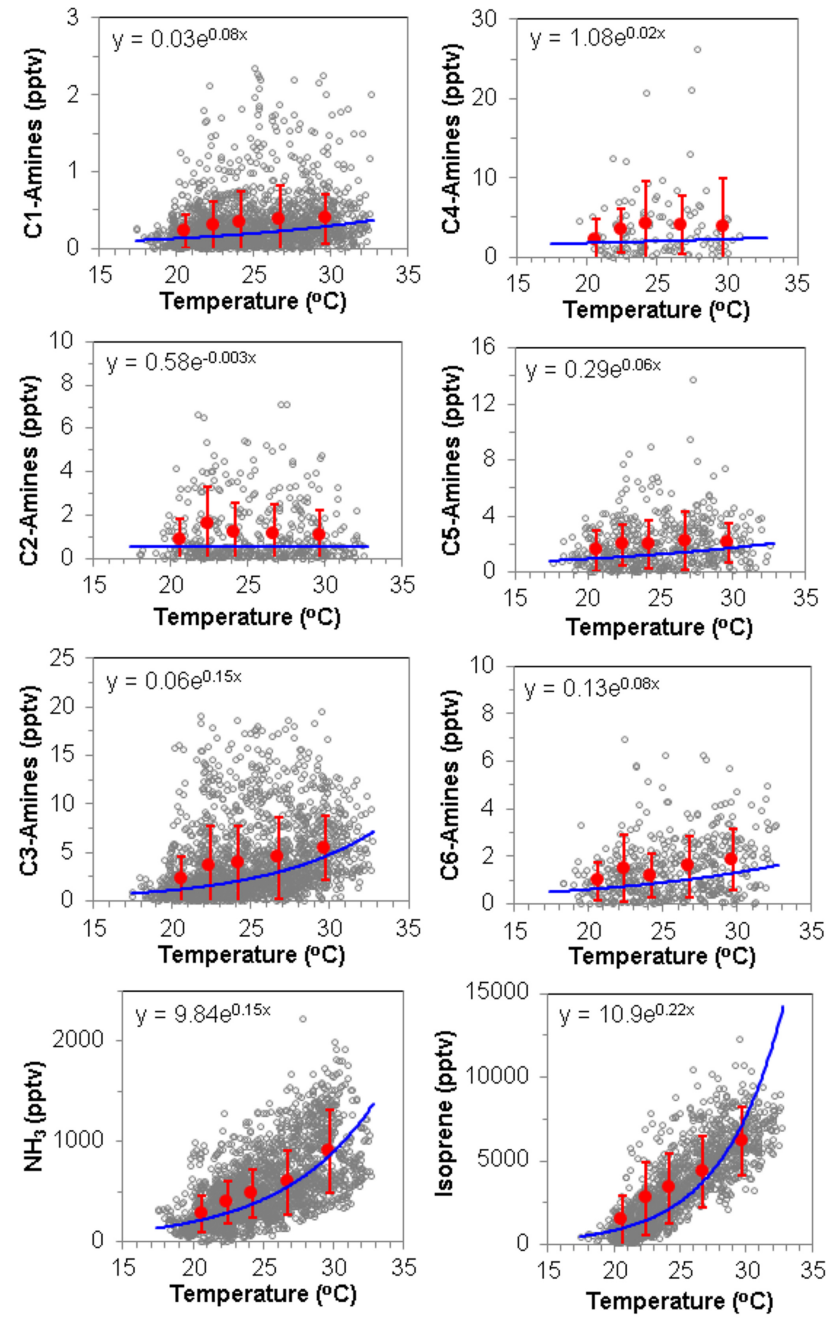

Figure 4. Temperature dependence of amines, $\mathrm{NH}_{3}$ and isoprene for the entire SOAS campaign. Gray dots show the measurement data and blue lines show exponential fitting of the data. Red circles and vertical lines show the mean and one standard deviation of concentrations of these chemical species, with each bin representing 20 percentile of temperature values.

pounds. Background signals were also independent of the ambient temperature and RH in our CIMS. On the other hand, there were some RH dependencies of background signals in the PTR-MS and because of the varying background signals, so the AmPMS did not report $\mathrm{NH}_{3}$ concentrations, simultaneously with amines (Hanson et al., 2011).

\section{Supporting measurements during the SOAS campaign}

During the SOAS campaign, a large number of state-of-art analytical instruments were deployed for aerosol and trace gas measurements (http://soas2013.rutgers.edu/). Here, we briefly describe specific measurements used in the present 


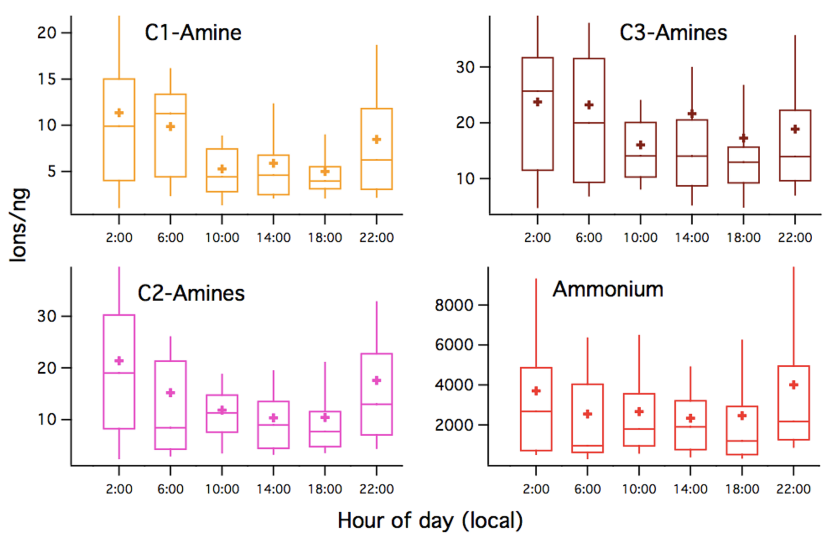

Figure 5. Campaign-averaged, 4-hour-binned C1- to C3-amines and ammonium particle-phase signals from TDCIMS. Line endpoints are the 10th and 90th percentile, bottom and top of the box indicates 25 th and 75 th percentile, horizontal lines are the median and the crosses are the mean. The ion data used were backgroundcorrected, detectable (2-sigma) points from $30 \mathrm{~min}$ particle collections and are mass-normalized by the collected particle mass. Collected particle masses ranged from 2-80 ng, and volume mean diameters for collected particles ranged from $40-120 \mathrm{~nm}$.

study. Aerosol-phase amines were measured with two independent methods. First, dried submicron particles were collected on PTFE filters and analyzed with Fourier transform infrared spectroscopy (FTIR) to identify functional groups of chemical components (including primary amines) in the aerosol phases. The samples were collected at either ambient temperature, $50^{\circ} \mathrm{C}$ or $70^{\circ} \mathrm{C}$; the analyzed amine concentrations were invariant with temperature so the reported values reflect averaged values between two co-located sampling lines. Additionally, chemical composition of particles in the size range from $\sim 40-120 \mathrm{~nm}$ was measured with an online thermal-desorption chemical ionization mass spectrometer (TDCIMS) (Smith et al., 2008; Smith et al., 2010). The collected particle masses ranged from 2-80 ng, and volume mean diameters for collected particles ranged from 40 $120 \mathrm{~nm}$. Thus, the FTIR and TDCIMS measurements represent chemical information of aerosols for different size ranges and for different types of amine compounds. Continuous analysis of $\mathrm{PM}_{2.5}$ mass was made with a tapered element oscillating microbalance (TEOM; R\&P, Model $1400 \mathrm{a} / \mathrm{b}$ ). Aerosol $\mathrm{pH}$ and particle water content were predicted, based on the ISORROPIA aerosol thermodynamic model (Fountoukis and Nenes, 2007; Nenes et al., 1998) and organic and inorganic anions and cations detected with ion chromatography (Guo et al., 2014). An in situ gas chromatographymass spectrometry (GC-MS) instrument was used to measure a large suite of VOCs, including isoprene, monoterpenes and their oxidation products, and the biomass burning tracer acetonitrile $\left(\mathrm{CH}_{3} \mathrm{CN}\right)$. Sample air was drawn from the top of the flux tower at the SOAS ground site, and VOCs were cryo-statically sampled for 5 minutes every half hour.
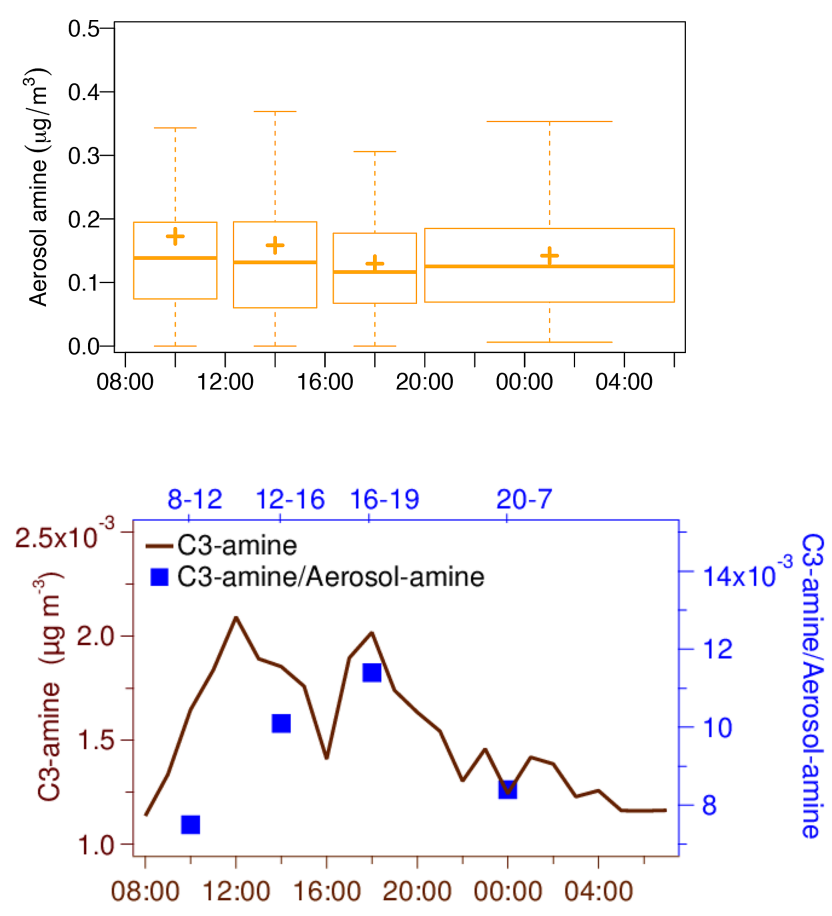

Figure 6. (Upper panel) Average daily variation of aerosol phase concentration $\left(\mu \mathrm{g} \mathrm{m}^{-3}\right)$ of primary amines in submicron particles collected on PTFE filters and analyzed with FTIR during the SOAS campaign. The horizontal solid lines indicate the median, plus signs indicate the mean, the boxes extend from the 25th to 75th percentile, and the whiskers span the interquartile range. (Lower panel) Temporal variation of the averaged gas-phase $\mathrm{C} 3$-amines (brown line) and the ratio of $\mathrm{C} 3$-amines over the aerosol-phase aliphatic amines (blue squares) during the SOAS campaign. The unit of gas-phase $\mathrm{C} 3$-amine concentrations was converted from pptv to $\mu \mathrm{g} \mathrm{m}^{-3}\left(1 \mathrm{pptv}=0.41 \mathrm{ng} \mathrm{m}^{-3}\right)$ to be compared with aerosolphase amines. Since C3-amines dominated for most of the SOAS campaign (Figs. 2 and 3), C3-amines can be representative of the total gas phase amine concentrations.

A detailed description of the instrument can be found elsewhere (Gilman et al., 2010). OH radicals were detected with the laser induced fluorescence (LIF) technique (Mao et al., 2012). Ozone was measured with a pressure and temperature compensated UV absorption instrument TEI-49i (Thermo Scientific). $\mathrm{SO}_{2}$ was measured by pulsed UV fluorescence (model TEI 43C-TL). Ambient temperature and RH were monitored with the Met4 Measurement System (Paroscientific Inc.). Wind speed and direction were measured with an ultra-sonic anemometer (R. M. Young, model 81000).

\section{Measurements in the Alabama forest}

Table 1 shows the summary of the ambient concentrations of amines and $\mathrm{NH}_{3}$ measured in the Alabama forest in June and July 2013. Temporal variations of amines and $\mathrm{NH}_{3}$ are shown for the 6 weeks of the entire SOAS campaign period (Fig. 2). 


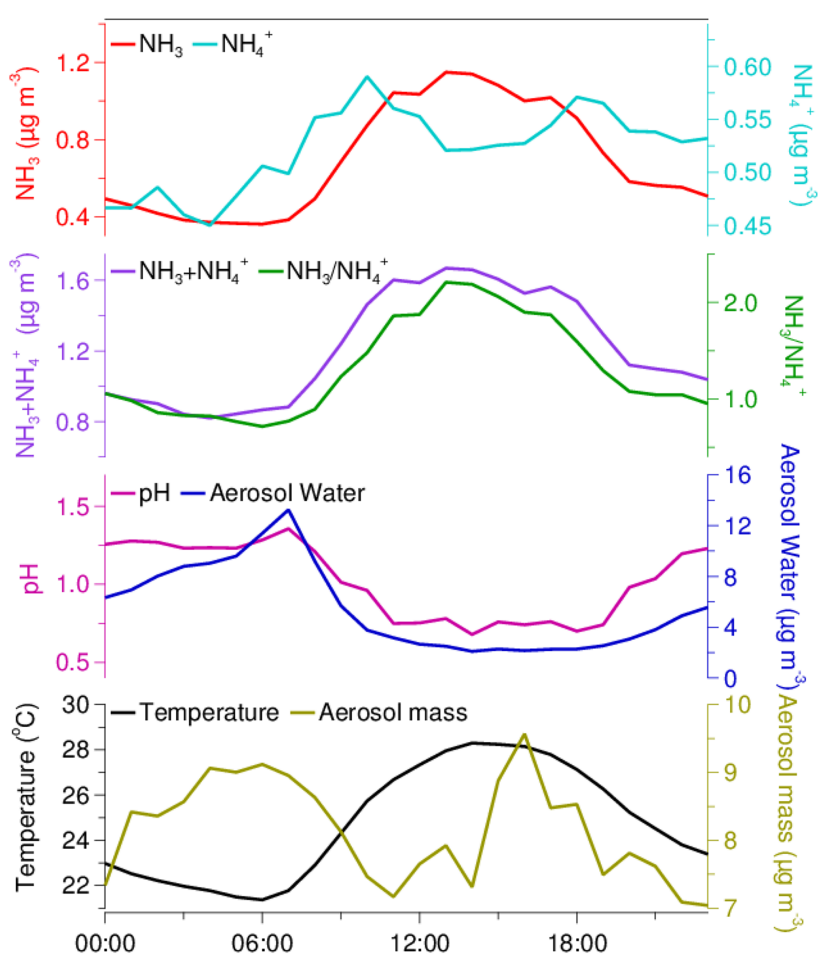

Figure 7. The average diurnal variation of the gas phase $\mathrm{NH}_{3}$ (red), aerosol-phase ammonium $\left(\mathrm{NH}_{4}^{+}\right.$, cyan) measured with ion chromatography (IC), the sum of $\mathrm{NH}_{3}$ and $\mathrm{NH}_{4}^{+}$(purple), the ratio of $\mathrm{NH}_{3}$ to $\mathrm{NH}_{4}^{+}$(green), ISORROPIA-predicted aerosol pH (magenta), ISORROPIA-predicted aerosol water content (blue), ambient temperature (black), and aerosol mass (yellow) for the entire SOAS campaign period. The unit of gas-phase $\mathrm{NH}_{3}$ concentrations was converted from ppbv to $\mu \mathrm{g} \mathrm{m}^{-3}\left(1 \mathrm{ppbv}=1.3 \mu \mathrm{g} \mathrm{m}^{-3}\right)$ to be compared with aerosol-phase $\mathrm{NH}_{4}^{+}$.

Typically, there were pptv or tens of pptv levels of C3-amines and ppbv or sub-ppbv levels of $\mathrm{NH}_{3}$ for most days. Other amines (C2- and C4- to C6-amines) were below the CIMS detection limits for most of the time. Figure 3 shows the averaged diurnal variation of amines and $\mathrm{NH}_{3}$ over the entire campaign, along with the measured ambient temperatures. C3-amines and $\mathrm{NH}_{3}$ showed distinctive diurnal variations with higher concentrations in the warmer afternoon temperatures and lower concentrations during the cooler night and the early morning temperatures. Thus, there were temperature dependencies of $\mathrm{C} 3$-amines and $\mathrm{NH}_{3}$ (Fig. 4). These temperature dependencies show that these basic compounds may be lost by deposition at night and then partition back to the atmosphere in the morning when the surface heating increased.

These temperature dependencies also indicate that these basic compounds were driven by the thermodynamic partitioning between the gas and aerosol phases. The thermodynamic effects can be more important for small molecular weight amine compounds, compared to larger amines, as the

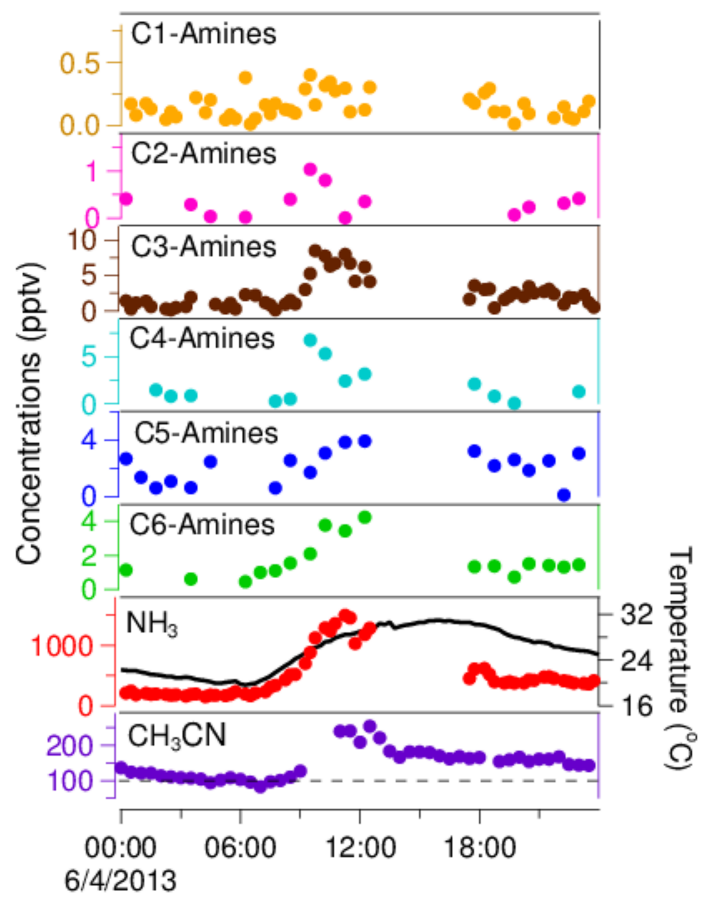

Figure 8. Amines, $\mathrm{NH}_{3}$ and $\mathrm{CH}_{3} \mathrm{CN}$ concentrations measured on 4 June 2014 in the Alabama forest. The measured ambient temperature is also shown. There was a local trash burning event starting around $10 \mathrm{a} . \mathrm{m}$. The blank period of amines and $\mathrm{NH}_{3}$ in the afternoon was due to a power outage in the trailer where the CIMS was located.

vapor pressure exponentially decreases with the increasing molecular weight (NIST, 2005). During SOAS, the TDCIMS measured various amines in particles in the size range from $\sim 40-120 \mathrm{~nm}$. The particle amine fractions showed diurnal variations (Fig. 5) opposite to the gas-phase amines (Fig. 3). There were higher fractional levels of aerosol-phase amines (C1-C3) during the night and in the early morning and lower levels from the late morning until the end of the day. These results indicate active gas to particle conversion of amines at this site. Consistent with these conclusions, the measured aerosol-phase aliphatic primary amine concentrations measured with FTIR from micron and submicron particles were nearly 2 orders of magnitude higher than gas phase amines (in this case, mostly C3-amines) (Fig. 6). These results show that aliphatic amines were primarily present in the aerosol phases, rather than gas phase, at this forest site. On the other hand, the sum of the $\mathrm{NH}_{3}$ and the aerosol-phase $\mathrm{NH}_{4}^{+}$measured in particles ranged from $\sim 0.8 \mu \mathrm{g} \mathrm{m}^{-3}$ in the evening up to $\sim 1.6 \mu \mathrm{g} \mathrm{m}^{-3}$ in the afternoon (Fig. 7).

To quantitatively explain this difference, we have performed a simple calculation to determine the likelihood of gas to particle conversion of an amine versus ammonia. In our calculation, we considered only Henry's Law equilibrium and acid dissociation, and neglected salt formation. Henry's Law constants are quite similar for an alkali amine and am- 

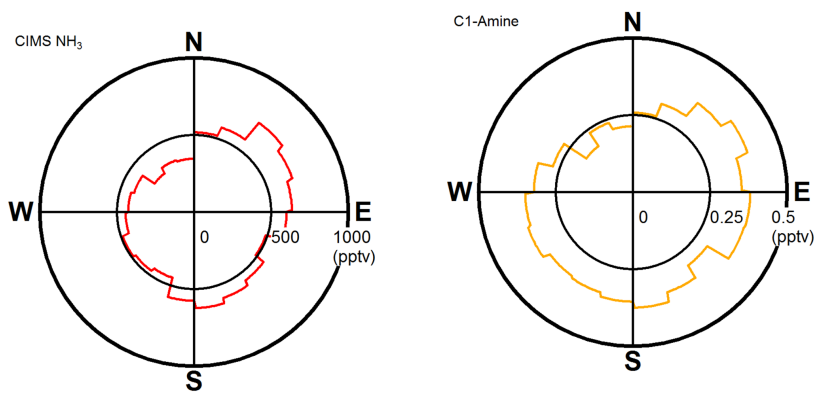

showed that the highest concentrations of C3- to C6-amines and $\mathrm{NH}_{3}$ were from the southeast direction (Fig. S3), where the burning took place. Clearly, the detection of such rapid evolution of ambient amines was enabled with the fast response CIMS technique. During the last week of June when the site was affected by the transported biomass burning air masses, as indicated by high concentrations of acetonitrile $\left(\mathrm{CH}_{3} \mathrm{CN}\right)$ (reaching up to $250 \mathrm{pptv}$ ), various amines (C1-C6) were also observed at the pptv level (Fig. 2). The global background concentrations of acetonitrile are around $100 \mathrm{pptv}$ (de Gouw et al., 2003; Warneke et al., 2006), so this elevated level indicates the presence of biomass burning emissions. On the other hand, the strong diurnal variation observed in acetonitrile was quite unusual and may indicate the importance of nighttime surface deposition. Compared to the other days where mostly $\mathrm{C} 3$-amines and $\mathrm{NH}_{3}$ were measured, these higher concentrations of various amines indicate that biomass burning is an important emission source of amines in the southeastern US.

Wind direction analysis showed that these basic compounds originated from a similar direction (mostly northeast, Fig. 9) during the campaign period. Three-way catalytic converters have been used in automobile engines and power plants in the recent years and they have become an important source of anthropogenic reduced nitrogen compounds in the atmosphere (Ge et al., 2010b; Nowak et al., 2012). We made systematic analysis for each day of the entire campaign, and we found that regardless of wind direction, time of the day (e.g., rush hours) or day in the week, amines and $\mathrm{NH}_{3}$ concentrations measured were not associated with $\mathrm{SO}_{2}$ and $\mathrm{CO}$ plumes (e.g., Fig. S4). Therefore, it is unlikely that the power plants, traffic, and industry activities were a direct source of amines in this relatively rural forest.

Concentrations of $\mathrm{C} 3$-amines and $\mathrm{NH}_{3}$ detected in the $\mathrm{Al}$ abama forest showed some exponential dependencies on the ambient temperature, like isoprene (Fig. 4). Such exponential temperature dependencies, as typically found for BOVCs emitted from trees (Guenther et al., 1995), may suggest some biogenic sources of $\mathrm{C} 3$-amines. But there is also caveat in this interpretation, because the temperature dependence was also simply due to the dominant gas-to-particle conversion process, as discussed above.

Throughout the SOAS campaign, amines and $\mathrm{NH}_{3}$ concentrations dropped considerably during rain events, as a general trend. For example, in July with a long period of rain, $\mathrm{C} 3$-amines were only at the pptv and $\mathrm{NH}_{3}$ at the subppbv level (Fig. 2). These results show that wet deposition is one of the important sink processes of amines and $\mathrm{NH}_{3}$ in the atmosphere.

conversion than for ammonia, based on their Henry's Law constants and acid dissociation rates.

Figure 8 shows that amines were emitted from burnings. There was a local trash-burning event that took place near the site around $10 \mathrm{a} . \mathrm{m}$. on 4 June 2013. An abrupt increase of $\mathrm{C} 3$ - to C6-amines (up to $10 \mathrm{pptv}$ ) and $\mathrm{NH}_{3}$ concentrations occurred during this burning event. Wind direction plots 


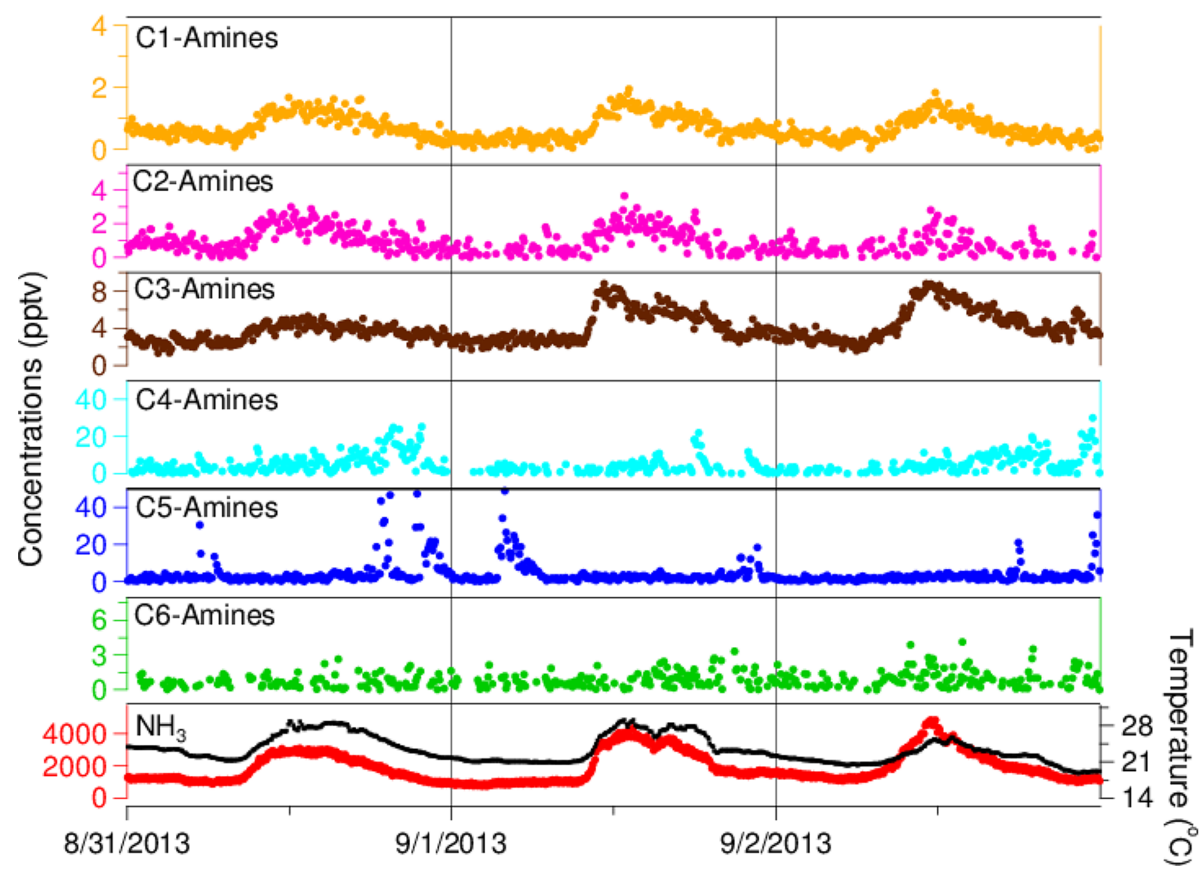

Figure 10. A typical 3-day ambient measurement of amines and $\mathrm{NH}_{3}$ in Kent, Ohio. Ambient temperatures are also included here. Vertical bars show times at midnight.

\section{Measurements in a moderately polluted continental environment}

Table 1 also shows a summary of the ambient concentrations of amines and $\mathrm{NH}_{3}$ measured in Kent over 20 days in $\mathrm{Au}-$ gust and September. Figure 10 shows the temporal variation of amines and $\mathrm{NH}_{3}$ during the 3 typical days within the measurement period (31 August to 2 September). The concentrations of $\mathrm{C} 1$-amine were up to $4 \mathrm{pptv}, \mathrm{C} 2$-amines lower than the detection limit (DL), C3-amines up to $10 \mathrm{pptv}, \mathrm{C} 4$-amines between 20-50 pptv, C5-amines between 20-100 pptv, C6amines lower than DL, and $\mathrm{NH}_{3}$ up to 6 ppbv. $\mathrm{C} 1$ - through C3-amines and $\mathrm{NH}_{3}$ showed very similar temporal variations as the ambient temperature, with higher concentrations in the afternoon, showing that they were controlled by the similar emission and loss processes. The strong temperature dependencies (Fig. S5) also imply that these low molecular weight amines and $\mathrm{NH}_{3}$ were involved in gas-particle partitioning processes. On the other hand, C4- to C6-amines had some abrupt and frequent increases during the night and did not follow the temporal trend of the ambient temperature, suggesting some local emission sources of these amines.

During the winter season, $\mathrm{C} 2$ - and $\mathrm{C} 3$-amines were at the ppbv and tens of ppbv range at the same site (Yu and Lee, 2012). In comparison, there were higher concentrations of amines and $\mathrm{NH}_{3}$ during the summer (Fig. 10), likely due to higher ambient temperatures. $\mathrm{NH}_{3}$ concentrations reported here are within the same range as those previously reported from the same site (Benson et al., 2010; Erupe et al., 2010).

\section{Discussion and conclusions}

We have measured amines and $\mathrm{NH}_{3}$ during the summer in two different atmospheric environments. In the rural southeastern US forest, there were mostly $\mathrm{C} 3$-amines (up to 15 pptv) and $\mathrm{NH}_{3}$ (up to $2 \mathrm{ppbv}$ ), whereas in the moderately polluted Ohio site, there were more abundant amines ( $\mathrm{C} 1-$ C6, pptv and tens of pptv) and $\mathrm{NH}_{3}$ (up to $6 \mathrm{ppb}$ ) (Table 1). These different $\mathrm{NH}_{3}$ concentrations measured at these two sites in the same summer of the same year are consistent with EPA-reported annual emission rates of $\mathrm{NH}_{3}$ from various sectors in Alabama and Ohio states (Fig. S6). Atmospheric lifetime of $\mathrm{NH}_{3}$ is typically several days, so emissions and transport at the regional scale can influence the measured concentrations of $\mathrm{NH}_{3}$. The amine concentrations measured in the Alabama forest were lower than those reported from an urban environment in the southeastern US (Atlanta, Georgia) (Hanson et al., 2011). The Hanson et al. (2011) study reported C6-amines up to $25 \mathrm{pptv}, \mathrm{C} 3$-amines up to $15 \mathrm{pptv}$, and $\mathrm{C} 1$-amine up to $3 \mathrm{pptv}$. While the concentrations of amines were generally lower in the Alabama forest, various C1- through C6-amines were present at the pptv level when there were transported biomass burning plumes (Figs. 2 and 8).

Currently, very limited information is available for the land-atmosphere emissions and deposition processes of amines (Hertel et al., 2013). However, some qualitative conclusions can be made to explain the generally low background concentrations of amines observed in the Alabama 
forest. First, oxidation reactions are an important chemical process for amines in the southeastern US especially during the summer - as amines efficiently react with atmospheric oxidants such as $\mathrm{OH}$, ozone, and $\mathrm{NO}_{3}$ in the atmosphere (Finlayson-Pitts and Pitts, 2000; Nielsen et al., 2011, 2012). During the SOAS field campaign, $\mathrm{OH}$ concentrations measured with LIF were $\sim 2 \times 10^{6} \mathrm{~cm}^{-3}$ at noontime. Ozone concentrations were $30 \pm 12$ ppbv during the daytime and $21 \pm 10 \mathrm{ppbv}$ during nighttime. Under these high concentrations of oxidants, atmospheric lifetimes of amines can be as short as several hours. Second, wet deposition is an important sink process for amines and $\mathrm{NH}_{3}$, because of their high water solubilities. Henry's Law constants of amines (C1C6) and $\mathrm{NH}_{3}$ are $\sim 10-160 \mathrm{M} \mathrm{atm}^{-1}$ and $\sim 60 \mathrm{M} \mathrm{atm}^{-1}$, respectively (NIST, 2005; Sander, www.henrys-law.org/). Wet deposition can occur via rain, cloud and fog droplets, as well as onto the wet forest canopy and soil surfaces, especially under high RH conditions. The measured amines and $\mathrm{NH}_{3}$ concentrations indeed decreased during the rain events (Fig. 2). Third, dry deposition rates are also expected to be high for chemical compounds that have high Henry's Law constants (and hence small surface residence times) (Hertel et al., 2013). Uptake coefficient of basic compounds is also dependent on the aerosol acidity (ApSimon et al., 1994). During the SOAS campaign, there were high aerosol loadings, high aerosol water content, and strong acidity of aerosol particles (Fig. 7). On average, $\mathrm{PM}_{2.5}$ aerosols were composed of $1.8 \pm 1.1 \mu \mathrm{g} \mathrm{m}^{-3}$ sulfate, $0.1 \pm 0.1 \mu \mathrm{g} \mathrm{m}^{-3}$ nitrate, $0.6 \pm 0.3 \mu \mathrm{g} \mathrm{m}^{-3}$ ammonium, and $3.2 \pm 2.3 \mu \mathrm{g} \mathrm{m}^{-3}$ organic components. Aerosol water content ranged from 2$20 \mu \mathrm{g} \mathrm{m}^{-3}$ and the aerosol $\mathrm{pH}$ was generally lower than 3 for the entire SOAS campaign period. These factors together provided an ideal condition for strong uptake of semi-volatile basic compounds on aerosol particles.

Amines and $\mathrm{NH}_{3}$ are thought to be key nucleation precursors (Berndt et al., 2010; Erupe et al., 2011; Kirkby et al., 2011; Yu et al., 2012; Zollner et al., 2012). Previously, Kieloaho et al. (2013) showed there was not a direct correlation between amines ( $\mathrm{C} 2$ - to $\mathrm{C} 4$-amines) and new particle formation in the Finnish boreal forest, whereas at the same forest site Sellegri et al. (2005b) showed concentrations of $\mathrm{C} 3$-amines were higher during the particle formation events than non-event days. In Kent, there were more abundant amines (C1-C6) and $\mathrm{NH}_{3}$ in the summer (Table 1), and even in winter there were $\mathrm{C} 2$ - and $\mathrm{C} 3$-amines at pptv or tens pptv level (Yu and Lee, 2012). These basic compounds, together with high emissions of $\mathrm{SO}_{2}$ from the surrounding coal-burning power plants (and hence sulfuric acid production), may explain the frequent new particle formation events reported from this site (Erupe et al., 2010; Kanawade et al., 2012; Yu et al., 2013).

The Supplement related to this article is available online at doi:10.5194/acp-14-12181-2014-supplement.
Author contributions. SHL designed the research; YY, JAD, ABG, MRS, ML, JNS, ST, GR, AK, KO, KB, RJ, AN, HG, ESG, LP, WHB, AGH, and SHL conducted measurements; YY, VPK, SR, MRS, ML, JNS, ST, and GR performed data analysis; SHL wrote the manuscript with input from JAD, ABG, SM, ML, JNS, ST, AK, $\mathrm{KB}, \mathrm{RJW}$, and $\mathrm{AN}$; all coauthors commented on the manuscript.

Acknowledgements. We acknowledge funding support from National Science Foundation (NSF, AGS-1137821, AGS 1241498) for SHL; NSF for AN, HG, and RW; Swiss National Science Foundation (SNF 200021_143298) for ST. SHL also thanks Greg Huey, Dave Tanner, Huan Yu and Dave Benson for helpful conversations on CIMS; Janek Uin for assistance on the data reduction; Greg Frost and Charles Blanchard for discussions on ammonia emissions; Jessica Gilman and Brian Lerner for help with the gas chromatography measurements.

Edited by: J. Liggio

\section{References}

Akyüz, M.: Simultaneous determination of aliphatic and aromatic amines in indoor and outdoor air samples by gas chromatography-mass spectrometry, Talanta, 71, 486-492, 2007.

Almeida, J., Schobesberger, S., Kurten, A., Ortega, I. K., Kupiainen-Maatta, O., Praplan, A. P., Adamov, A., Amorim, A., Bianchi, F., Breitenlechner, M., David, A., Dommen, J., Donahue, N. M., Downard, A., Dunne, E., Duplissy, J., Ehrhart, S., Flagan, R. C., Franchin, A., Guida, R., Hakala, J., Hansel, A., Heinritzi, M., Henschel, H., Jokinen, T., Junninen, H., Kajos, M., Kangasluoma, J., Keskinen, H., Kupc, A., Kurten, T., Kvashin, A. N., Laaksonen, A., Lehtipalo, K., Leiminger, M., Leppa, J., Loukonen, V., Makhmutov, V., Mathot, S., McGrath, M. J., Nieminen, T., Olenius, T., Onnela, A., Petaja, T., Riccobono, F., Riipinen, I., Rissanen, M., Rondo, L., Ruuskanen, T., Santos, F. D., Sarnela, N., Schallhart, S., Schnitzhofer, R., Seinfeld, J. H., Simon, M., Sipila, M., Stozhkov, Y., Stratmann, F., Tome, A., Trostl, J., Tsagkogeorgas, G., Vaattovaara, P., Viisanen, Y., Virtanen, A., Vrtala, A., Wagner, P. E., Weingartner, E., Wex, H., Williamson, C., Wimmer, D., Ye, P., Yli-Juuti, T., Carslaw, K. S., Kulmala, M., Curtius, J., Baltensperger, U., Worsnop, D. R., Vehkamaki, H., and Kirkby, J.: Molecular understanding of sulphuric acid-amine particle nucleation in the atmosphere, Nature, 502, 359-363, 2013.

Angelino, S., Suess, D., and Prather, K.: Formation of aerosol particles from reactions of secondary and tertiary alkylamines: characterization by aerosol time-of-flight mass spectrometry, Environ. Sci. Technol., 35, 3130-3138, 2001.

ApSimon, H. M., Barker, B. M., and Kayin, S.: Modelling studies of the atmospheric release and transport of ammonia in anticyclonic episodes, Atmos. Environ., 28, 665-678, 1994.

Benson, D. R., Markovich, A., Al-Refai, M., and Lee, S.-H.: A Chemical Ionization Mass Spectrometer for ambient measurements of Ammonia, Atmos. Meas. Tech., 3, 1075-1087, doi:10.5194/amt-3-1075-2010, 2010. 
Berndt, T., Stratmann, F., Sipilä, M., Vanhanen, J., Petäjä, T., Mikkilä, J., Grüner, A., Spindler, G., Lee Mauldin III, R., Curtius, J., Kulmala, M., and Heintzenberg, J.: Laboratory study on new particle formation from the reaction $\mathrm{OH}+\mathrm{SO}_{2}$ : influence of experimental conditions, $\mathrm{H}_{2} \mathrm{O}$ vapour, $\mathrm{NH}_{3}$ and the amine tert-butylamine on the overall process, Atmos. Chem. Phys., 10, 7101-7116, doi:10.5194/acp-10-7101-2010, 2010.

Bigg, E. K.: Gas emissions from soil and leaf litter as a source of new particle formation, Atmos. Res., 70, 33-42, 2004.

Chang, I.-H., Lee, C.-G., and Lee, D. S.: Development of an automated method for simultaneous determination of low molecular weight aliphatic amines and ammonia in ambient air by diffusion scrubber coupled to ion chromatography, Anal. Chem., 75, 6141-6146, 2003.

Dawson, M. L., Perraud, V., Gomez, A., Arquero, K. D., Ezell, M. J., and Finlayson-Pitts, B. J.: Measurement of gasphase ammonia and amines in air by collection onto an ion exchange resin and analysis by ion chromatography, Atmos. Meas. Tech. Discuss., 7, 1573-1602, doi:10.5194/amtd-7-1573-2014, 2014.

de Gouw, J. A., Warneke, C., Parrish, D. D., Holloway, J. S., Trainer, M., and Fehsenfeld, F. C.: Emission sources and ocean uptake of acetonitrile $\left(\mathrm{CH}_{3} \mathrm{CN}\right)$ in the atmosphere, J. Geophys. Res., 108, 4329, doi:10.1029/2002JD002897, 2003.

De Haan, D., Tolbert, M., and Jimenez, J.: Atmospheric condensedphase reactions of glyoxal with methylamine, Geophys. Res. Lett., 36, L11819, doi:10.1029/2009GL037441, 2009.

Eisele, F. L.: First tandem mass spectrometric measurements of tropospheric ions, J. Geophys. Res., 93, 716-724, 1988.

Erupe, M. E., Benson, D. R., Li, J., Young, L.-H., Verheggen, B., Al-Refai, M., Tahboub, O., Cunningham, V., Frimpong, F., Viggiano, A. A., and Lee, S.-H.: Correlation of aerosol nucleation rate with sulfuric acid and ammonia in Kent Ohio: an atmospheric observation, J. Geophs. Res., 115, D23216, doi:10.1029/2010JD013942, 2010.

Erupe, M. E., Viggiano, A. A., and Lee, S.-H.: The effect of trimethylamine on atmospheric nucleation involving $\mathrm{H}_{2} \mathrm{SO}_{4}$, Atmos. Chem. Phys., 11, 4767-4775, doi:10.5194/acp-11-47672011, 2011.

Finlayson-Pitts, B. J. and Pitts, J. N.: Chemistry of the Upper and Lower Atmosphere: Theory, Experiments, and Applications, Academic Press, San Diego, CA, 2000.

Fountoukis, C. and Nenes, A.: ISORROPIA II: a computationally efficient thermodynamic equilibrium model for $\mathrm{K}^{+}-\mathrm{Ca}^{2+}-$ $\mathrm{Mg}^{2+}-\mathrm{NH}_{4}^{+}-\mathrm{Na}^{+}-\mathrm{SO}_{4}^{2-}-\mathrm{NO}_{3}^{-}-\mathrm{Cl}^{-}-\mathrm{H}_{2} \mathrm{O}$ aerosols, Atmos. Chem. Phys., 7, 4639-4659, doi:10.5194/acp-7-4639-2007, 2007.

Gai, Y., Ge, M., and Wang, W.: Rate constants for the gas phase reactions of ozone with diethylamine and triethylamine, Acta Physico-Chemica Sinica, 26, 1768-1772, 2010.

Ge, X., Wexler, A. S., and Clegg, S. L.: Atmospheric amines - Part II. thermodynamic properties and gas/particle partitioning, Atmos. Environ., 45, 561-577, 2010a.

Ge, X., Wexler, A. S., and Clegg, S. L.: Atmospheric amines Part I. a review, Atmos. Environ., 45, 524-546, $2010 \mathrm{~b}$.

Gilman, J. B., Burkhart, J. F., Lerner, B. M., Williams, E. J., Kuster, W. C., Goldan, P. D., Murphy, P. C., Warneke, C., Fowler, C., Montzka, S. A., Miller, B. R., Miller, L., Oltmans, S. J., Ryerson, T. B., Cooper, O. R., Stohl, A., and de Gouw, J. A.: Ozone variability and halogen oxidation within the Arctic and sub-Arctic springtime boundary layer, Atmos. Chem. Phys., 10, 10223-10236, doi:10.5194/acp-1010223-2010, 2010.

Guo, H., Xu, L., Bougiatioti, A., Cerully, K. M., Capps, S. L., Hite, J. R., Carlton, A. G., Lee, S.-H., Bergin, M. H., Ng, N. L., Nenes, A., and Weber, R. J.: Particle water and $\mathrm{pH}$ in the southeastern United States, Atmos. Chem. Phys. Discuss., 14, 27143-27193, doi:10.5194/acpd-14-27143-2014, 2014.

Grönberg, L., Lövkvist, P., and Jönsson, J.: Determination of aliphatic amines in air by membrane enrichment directly coupled to a gas chromatograph, Chromatographia, 33, 77-82, 1992.

Guenther, A. B., Hewitt, C. N., Erickson, D., Fall, R., Geron, C., Graedel, T., Harley, P., Klinger, L., Lerdau, M., McKay, W. A., Pierce, T., Scholes, B., Steinbrecher, R., Tallamraju, R., and Zimmerman, P.: A global model of natural volatile organic compound emissions, J. Geophys. Res., 100, 8873-8892, 1995.

Hanson, D. R., McMurry, P. H., Jiang, J., Tanner, D., and Huey, L. G.: Ambient pressure proton transfer mass spectrometry: detection of amines and ammonia, Environ. Sci. Technol., 45, 8881-8888, 2011.

Hertel, O., Reis, S., Skjøth, C. A., Bleeker, A., Harrison, R., Cape, J. N., Fowler, D., Skiba, U., Simpson, D., Jickells, T., Baker, A., Kulmala, M., Gyldenkærne, S., Sørensen, L. L., and Erisman, J. W.: Nitrogen processes in the atmosphere, Philos. T. Roy. Soc., 368, 177-207, 2013.

Jang, M., Czoschke, N. M., Lee, S., and Kamens, R. M.: Heterogeneous atmospheric aerosol production by acid-catalyzed particlephase reactions, Science, 298, 814-817, 2002.

Jolly, W. L.: Modern Inorganic Chemistry, 2nd edn., McGraw-Hill, New York, 1991.

Kanawade, V., Benson, D. R., and Lee, S.-H.: Statistical analysis of 4 year measurements of aerosol sizes in a semi-rural US continental environment, Atmos. Environ., 59, 30-38, 2012.

Karl, M.: Atmospheric Degradation of Amines (ADA) Amines in aerosol - a Review, Norwegian Institute for Air Research, Kjeller, Norway, 2010.

Kieloaho, A.-J., Hellén, H., Hakola, H., Manninen, H. E., Nieminen, T., Kulmala, M., and Pihlatie, M.: Gas-phase alkylamines in a boreal Scots pine forest air, Atmos. Environ., 80, 369-377, 2013.

Kirkby, J., Curtius, J., Almeida, J., Dunne, E., Duplissy, J., Ehrhart, S., Franchin, A., Gagne, S., Ickes, L., Kurten, A., Kupc, A., Metzger, A., Riccobono, F., Rondo, L., Schobesberger, S., Tsagkogeorgas, G., Wimmer, D., Amorim, A., Bianchi, F., Breitenlechner, M., David, A., Dommen, J., Downard, A., Ehn, M., Flagan, R. C., Haider, S., Hansel, A., Hauser, D., Jud, W., Junninen, H., Kreissl, F., Kvashin, A., Laaksonen, A., Lehtipalo, K., Lima, J., Lovejoy, E. R., Makhmutov, V., Mathot, S., Mikkila, J., Minginette, P., Mogo, S., Nieminen, T., Onnela, A., Pereira, P., Petaja, T., Schnitzhofer, R., Seinfeld, J. H., Sipila, M., Stozhkov, Y., Stratmann, F., Tome, A., Vanhanen, J., Viisanen, Y., Vrtala, A., Wagner, P. E., Walther, H., Weingartner, E., Wex, H., Winkler, P. M., Carslaw, K. S., Worsnop, D. R., Baltensperger, U., and Kulmala, M.: Role of sulphuric acid, ammonia and galactic cosmic rays in atmospheric aerosol nucleation, Nature, 476, 429-433, 2011.

Kurtén, T., Loukonen, V., Vehkamäki, H., and Kulmala, M.: Amines are likely to enhance neutral and ion-induced sulfuric acid-water nucleation in the atmosphere more effectively than ammonia, At- 
mos. Chem. Phys., 8, 4095-4103, doi:10.5194/acp-8-4095-2008, 2008.

Laskin, J., Laskin, A., Roach, P. J., Slysz, G. W., Anderson, G. A., Nizkorodov, S. A., Bones, D. L., and Nguyen, L. Q.: Highresolution desorption electrospray ionization mass spectrometry for chemical characterization of organic aerosols, Anal. Chem., 82, 2048-2058, 2010.

Lee, D. and Wexler, A. S.: Atmospheric amines - Part III: Photochemistry and toxicity, Atmos. Environ., 71, 95-103, 2013.

Lloyd, J., Heaton, K., and Johnston, M.: Reactive uptake of trimethylamine into ammonium nitrate particles, J. Phys. Chem. A, 113, 4840-4843, 2009.

Malloy, Q. G. J., Li Qi, Warren, B., Cocker III, D. R., Erupe, M. E., and Silva, P. J.: Secondary organic aerosol formation from primary aliphatic amines with $\mathrm{NO}_{3}$ radical, Atmos. Chem. Phys., 9, 2051-2060, doi:10.5194/acp-9-2051-2009, 2009.

Mao, J., Ren, X., Zhang, L., Van Duin, D. M., Cohen, R. C., Park, J.H., Goldstein, A. H., Paulot, F., Beaver, M. R., Crounse, J. D., Wennberg, P. O., DiGangi, J. P., Henry, S. B., Keutsch, F. N., Park, C., Schade, G. W., Wolfe, G. M., Thornton, J. A., and Brune, W. H.: Insights into hydroxyl measurements and atmospheric oxidation in a California forest, Atmos. Chem. Phys., 12, 8009-8020, doi:10.5194/acp-12-8009-2012, 2012.

Murphy, S. M., Sorooshian, A., Kroll, J. H., Ng, N. L., Chhabra, P., Tong, C., Surratt, J. D., Knipping, E., Flagan, R. C., and Seinfeld, J. H.: Secondary aerosol formation from atmospheric reactions of aliphatic amines, Atmos. Chem. Phys., 7, 2313-2337, doi:10.5194/acp-7-2313-2007, 2007.

Nenes, A., Pandis, S., and Pilinis, C.: ISORROPIA: a new thermodynamic equilibrium model for multiphase multicomponent inorganic aerosols, Aquat. Geochem., 4, 123-152, 1998.

Nielsen, C. J., D’Anna, B., Karl, M., Aursnes, M., Boreave, A., Bossi, R., Bunkan, A. J. C., Glasius, M., Hallquist, M., Hansen, A.-M. K., Kristensen, K., Mikoviny, T., Maguta, M. M., Müller, M., Nguyen, Q., Westerlund, J., Salo, K., Skov, H., Stenstrøm, Y., and Wisthaler, A.: Atmospheric Degradation of Amines (ADA) Summary Report: Photo-Oxidation of Methylamine, Dimethylamine and Trimethylamine CLIMIT project no. 201604, Norwegian Institute for Air Research, Kjeller, Norway, 2011.

Nielsen, C. J., Herrmann, H., and Weller, C.: Atmospheric chemistry and environmental impact of the use of amines in carbon capture and storage (CCS), Chem. Soc. Rev., 41, 6684-6704, 2012.

NIST: NIST Standard Reference Database Number 69, edited, National Institute for Standard Technology (NIST) Chemistry Web Book, available at: http://webbook.nist.gov/chemistry/ (last access: 23 September 2013), 2011.

Nowak, J. B., Huey, L. G., Eisele, F. L., Tanner, D., Mauldin III, R. L., Cantrell, C. A., Kosciuch, E., and Davis, D.: Chemical ionization mass spectrometry technique for the detection of dimethylsulfoxide and ammonia, J. Geophys. Res., 107, 4363, doi:10.1029/2001JD001058, 2002.

Nowak, J. B., Huey, L. G., Russell, A. G., Tian, D., Neuman, J. A., Orsini, D., Sjostedt, S. J., Sullivan, A. P., Tanner, D. J., Weber, R. J., Nenes, A., Edgerton, E., and Fehsenfeld, F. C.: Analysis of urban gas phase ammonia measurements from the 2002 Atlanta Aerosol Nucleation and Real-Time Characterization Experiment (ANARChE), J. Geophys. Res., 111, D17308, doi:10.1029/2006JD007113, 2006.
Nowak, J. B., Newman, J. A., Kozai, K., Huey, L. G., Tanner, D., Holloway, J. S., Ryerson, T. B., Frost, G. L., McKeen, S. A., and Fehsenfeld, F. C.: A chemical ionization mass spectrometry technique for airborne measurements of ammonia, J. Geophys. Res., 112, D10S02, doi:10.1029/2006JD007589, 2007.

Nowak, J. B., Neuman, J. A., Bahreini, R., Brock, C. A., Middlebrook, A. M., Wollny, A. G., Holloway, J. S., Peischl, J., Ryerson, T. B., and Fehsenfeld, F. C.: Airborne observations of ammonia and ammonium nitrate formation over Houston, Texas, J. Geophys. Res., 115, D22304, doi:10.1029/2010jd014195, 2010.

Nowak, J. B., Neuman, J. A., Bahreini, R., Middlebrook, A. M., Holloway, J. S., McKeen, S. A., Parrish, D. D., Ryerson, T. B., and Trainer, M.: Ammonia sources in the California South Coast Air Basin and their impact on ammonium nitrate formation, Geophys. Res. Lett., 39, L07804, doi:10.1029/2012g1051197, 2012.

Pankow, J. F.: Gas/particle partitioning of neutral and ionizing compounds to single and multi-phase aerosol particles, 1. Unified modeling framework, Atmos. Environ., 37, 3323-3333, 2003.

Pratt, K., Hatch, L., and Prather, K.: Seasonal volatility dependence of ambient particle phase amines, Environ. Sci. Technol., 43, 5276-5281, 2009.

Qiu, C. and Zhang, R.: Multiphase chemistry of atmospheric amines, Phys. Chem. Chem. Phys., 15, 5738-5752, 2013.

Sander, R.: Compilation of Henry's Law Constants for Inorganic and Organic Species of Potential Importance in Environmental Chemistry, available at: http://www.henrys-law.org/ (last access: 20 September 2013), 1999.

Schade, G. W. and Crutzen, P. J.: Emissions of aliphatic amines from animal husbandry and their reactions: potential source of $\mathrm{N}_{2} \mathrm{O}$ and HCN, J. Atmos. Chem., 22, 319-346, 1995.

Sellegri, K., Umann, B., Hanke, M., and Arnold, F.: Deployment of a ground-based CIMS apparatus for the detection of organic gases in the boreal forest during the QUEST campaign, Atmos. Chem. Phys., 5, 357-372, doi:10.5194/acp-5-357-2005, 2005a.

Sellegri, K., Hanke, M., Umann, B., Arnold, F., and Kulmala, M.: Measurements of organic gases during aerosol formation events in the boreal forest atmosphere during QUEST, Atmos. Chem. Phys., 5, 373-384, doi:10.5194/acp-5-373-2005, 2005 b.

Shao, R. J. and Stangeland, A.: Amines Used in $\mathrm{CO}_{2}$ Capture, edited, Bellona Report, Oslo, Norway, 2009.

Silva, P., Erupe, M., Price, D., Elias, J., Malloy, Q., Li, Q., Warren, B., and Cocker III, D.: Trimethylamine as precursor to secondary organic aerosol formation via nitrate radical reaction in the atmosphere, Environ. Sci. Technol., 42, 4689-4696, 2008.

Smith, J. N., Dunn, M. J., VanReken, T. M., Iida, K., Stolzenburg, M. R., McMurry, P. H., and Huey, L. G.: Chemical composition of atmospheric nanoparticles formed from nucleation in Tecamac, Mexico: evidence for an important role for organic species in nanoparticle growth, Geophys. Res. Lett., 35, L04808, doi:10.1029/2007GL032523, 2008.

Smith, J. N., Barsanti, K. C., Friedli, H. R., Ehn, M., Kulmala, M., Collins, D. R., Scheckman, J. H., Willians, B. J., and McMurry, P. H.: Observations of amonium salts in atmospheric nanoparticles and possible climatic implications, P. Natl. Acad. Sci. USA, 107, 6634-6639, 2010.

Surratt, J. D., Kroll, J. H., Kleindienst, T. E., Edney, E. O., Claeys, M., Sorooshian, A., Ng, N. L., Offenberg, J. H., Lewandowski, M., Jaoui, M., Flagan, R. C., and Seinfeld, J. H.: Evidence for 
organosulfates in secondary organic aerosol, Environ. Sci. Technol., 41, 517-527, 2007.

Sutton, M. A., Dragosits, U., Tang, Y. S., and Fowler, D.: Ammonia emissions from non-agricultural sources in the UK, Atmos. Environ., 34, 855-869, 2000.

Updyke, K. M., Nguyen, T. B., and Nizkorodov, S. A.: Formation of brown carbon via reactions of ammonia with secondary organic aerosols from biogenic and anthropogenic precursors, Atmos. Environ., 63, 22-31, 2012.

Vaden, T. D., Imre, D., Beránek, J., Shrivastava, M., and Zelenyuk, A.: Evaporation kinetics and phase of laboratory and ambient secondary organic aerosol, P. Natl. Acad. Sci. USA, 108, 2190-2195, 2011.

VandenBoer, T. C., Petroff, A., Markovic, M. Z., and Murphy, J. G.: Size distribution of alkyl amines in continental particulate matter and their online detection in the gas and particle phase, Atmos. Chem. Phys., 11, 4319-4332, doi:10.5194/acp-11-43192011, 2011.

Wang, L., Lal, V., Khalizov, A., and Zhang, R.: Heterogeneous chemistry of alkylamines with sulfuric acid: implications for atmospheric formation of alkylaminium sulfates, Environ. Sci. Technol., 44, 2461-2465, 2010a.

Wang, L., Khalizov, A., Zheng, J., Xu, W., Ma, Y., Lal, V., and Zhang, R.: Atmospheric nanoparticles formed from heterogeneous reactions of organics, Nat. Geosci., 3, 238-242, $2010 \mathrm{~b}$.

Warneke, C., Gouw, J. A. d., Stohl, A., Cooper, O. R., Goldan, P. D., Kuster, W. C., Holloway, J. S., Williams, E. J., Lerner, B. M., McKeen, S. A., Trainer, M., Fehsenfeld, F. C., Atlas, E. L., Donnelly, S. G., Stroud, V., Lueb, A., and Kato, S.: Biomass burning and anthropogenic sources of CO over New England in the summer 2004, J. Geophys. Res., 111, D23S15, doi:10.1029/2005JD006878, 2006.
Yu, H. and Lee, S.-H.: A chemical ionization mass spectrometer for the detection of atmospheric amines, Environ. Chem., 9, 190201, 2012.

Yu, H., McGraw, R., and Lee, S.-H.: Effects of amines on formation of sub-3 nm particles and their subsequent growth, Geophys. Res. Lett., 39, L02807, 2012.

Yu, H., Kanawade, V. P., You, Y., Hallar, A. G., Mccubbin, I. B., Chirokova, G., Sedlacek, A. J., Springston, S. R., Wang, J., McGraw, R. L., Mikkila, J., and Lee, S. H.: Sub-3 nm particles observed at the coastal and continental sites in the United States, J. Geophys. Res. Atmos., 119, doi:10.1002/2013JD020841, 2014.

Yu, Z., Zhang, Q., Kraus, T. E. C., Dahlgren, R. A., Anastasio, C., and Zasoski, R. J.: Contribution of amino compounds to dissolved organic nitrogen in forest soils, Biogeochemistry, 61, 173-198, 2002.

Zahardis, J., Geddes, S., and Petrucci, G. A.: The ozonolysis of primary aliphatic amines in fine particles, Atmos. Chem. Phys., 8, 1181-1194, doi:10.5194/acp-8-1181-2008, 2008.

Zhang, R., Khalizov, A., Wang, L., Hu, M., and Xu, W.: Nucleation and growth of nanoparticles in the atmosphere, Chem. Rev., 112, 957-2011, 2012.

Zollner, J. H., Glasoe, W. A., Panta, B., Carlson, K. K., McMurry, P. H., and Hanson, D. R.: Sulfuric acid nucleation: power dependencies, variation with relative humidity, and effect of bases, Atmos. Chem. Phys., 12, 4399-4411, doi:10.5194/acp-124399-2012, 2012. 